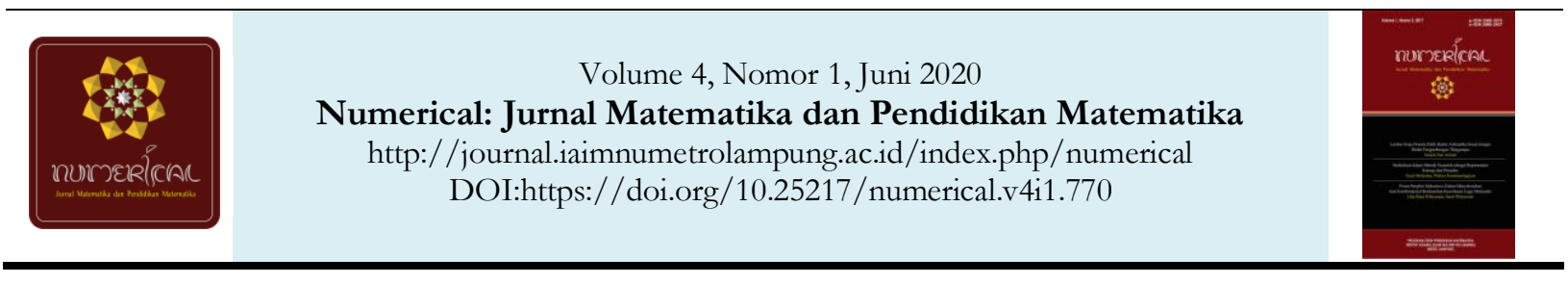

\title{
Effectiveness of Scaffolding Strategies in Learning Against Decrease in Mathematics Anxiety Level
}

\author{
Imam Kusmaryono ${ }^{1}$, Akbar Muntoha Gufron ${ }^{2}$, Achmad Rusdiantoro ${ }^{3}$
}

\author{
1,2 Department of Mathematics Education, Universitas Islam Sultan Agung, Semarang. \\ ${ }^{3}$ State Senior High School 6 Semarang. \\ Correspondence: $\square$ kusmaryono@unissula.ac.id
}

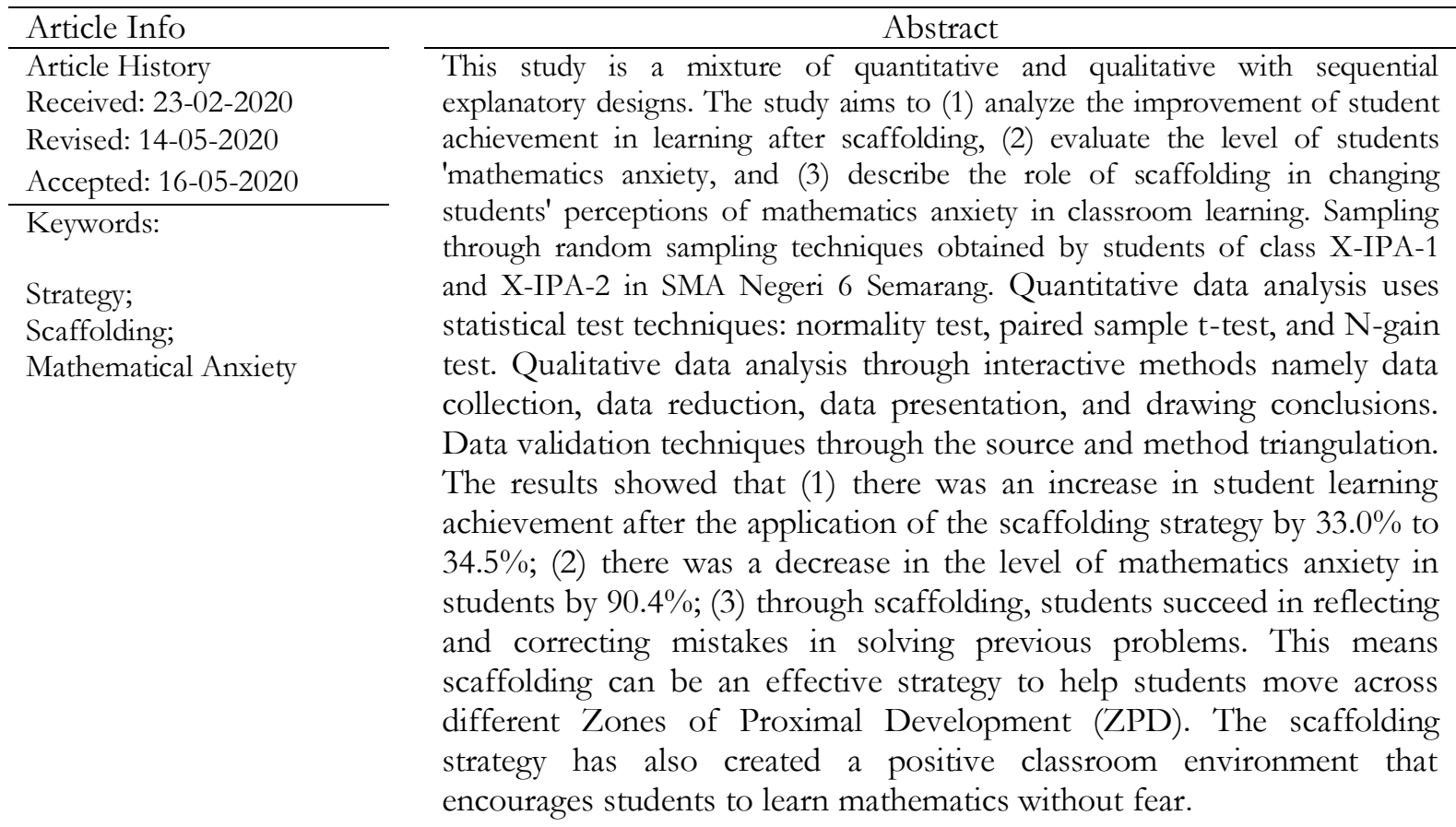

\section{INTRODUCTION}

Learning is an active interaction process between learners and instructor that does not happen in an empty space. Various characteristics of student and school background have created context as factors to influence the learning process and outcomes. The factors are mostly under teacher or school control. Mathematics in its true meaning is a science of space and quantity assisting to solve problems that require calculation and critical thinking [1]. Basically, mathematics learning is an effort to accommodate students to acquire mathematical knowledge, skill, interest and attitude [2]. Mathematics learning could influence the attitude in which the learner uses the knowledge practically [3][4][5].

Mastering skills in mathematics is often considered as special skills and more prestigious than any other skills in other fields. Moreover, there is such a public assumption that a student is not clever if the mathematics score is not good. Some students then have such mathematical anxiety toward the assumption. The mathematical anxiety is defined in any kinds of literatures as 
a feeling of anxiety (worry), tension, apprehension and fear experienced by a person in a situation involving mathematical problem-solving in daily life and academic situation [6]-[8].

Students are required to be competent in mathematics. Unfortunately, it is not followed by teacher performance in mathematics learning at school. A few teachers provide unattractive learning, lack of motivation and challenge, and only focusing on the problem-solving procedure, but less notice on affective aspects that support the mathematics learning successfulness [9]. It is because the conventional learning centring on the teacher only increase students' anxiety level and decrease their interest and disposition in mathematics learning [9],[10]. From the students' perspective, high hopes voiced for the teacher to help them learn mathematics successfully, reduce anxiety and increase self-confidence through teacher's assistance and support in mathematics performance. The mathematics anxiety begins with negative experience toward mathematics or the teacher [12]-[14].

Scaffolding is a teaching strategy that describes a process of supporting students to acquire goals of learning or, in short, to help students succeed in learning [14],[15]. Scaffolding is learning assistance by a teacher to students who have obstacles in learning. The learning will be more effective if the teacher could help to develop the students' cognitive structure for their independent learning someday [10]. Vygotskian suggested that instructors should effectively cope with each student's zona of proximal development (ZPD) through scaffolding [17].

Scaffolding is given when students conduct a reflection process on their work by directing their initial knowledge to solve problems they have [10]. Stages of conducting scaffolding strategy in learning are described below.

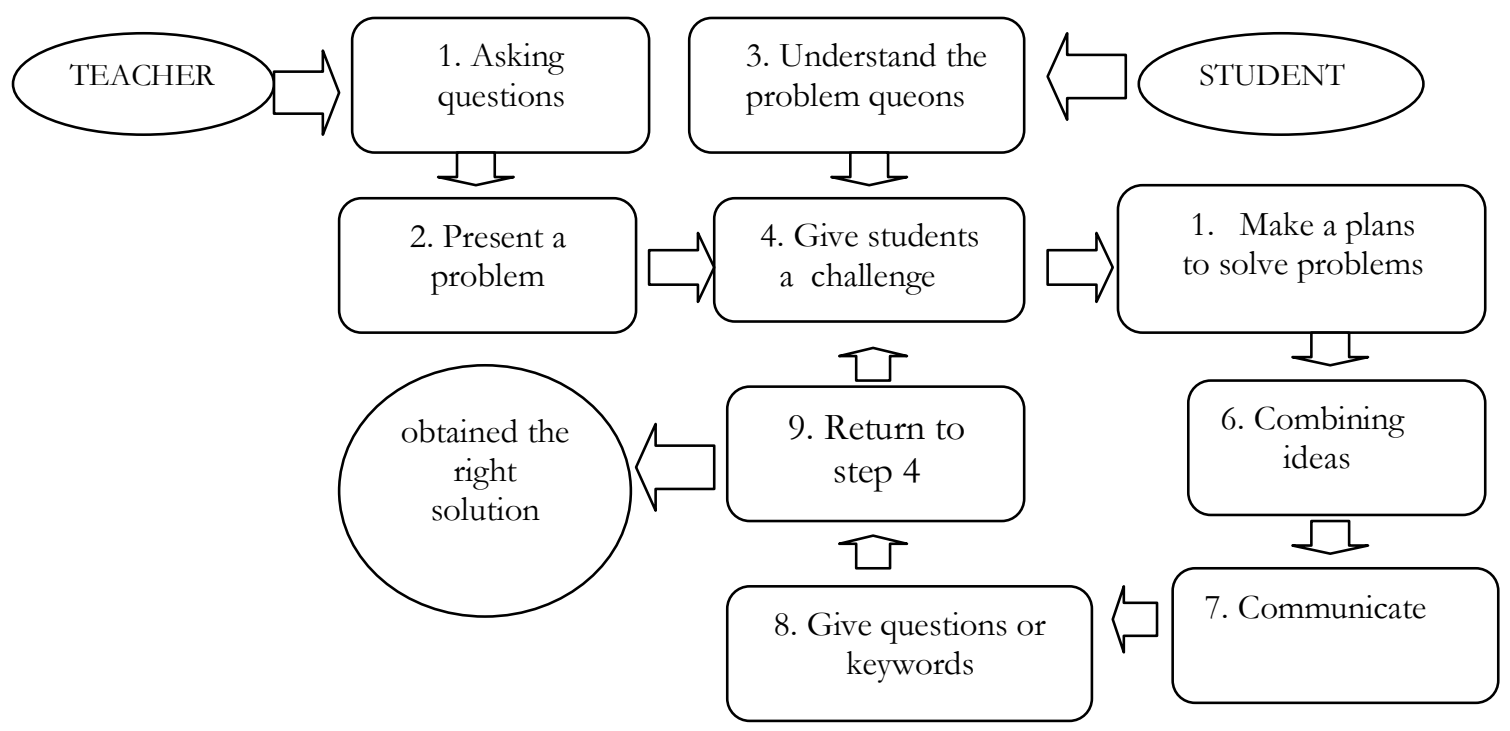

Figure 1. Steps in Scaffolding Strategy

Purposes of this study specifically are to (1) analyze the improvement of student's learning achievement after having scaffolding in learning, (2) evaluate the level of students' mathematics anxiety before and after gaining scaffolding treatment in learning, and (3) identify the role of scaffolding in changing students' perception toward mathematics learning. 


\section{RESEARCH METHOD}

The authors designed this study by collaborating quantitative and qualitative methods within a sequential explanatory design [18]. Through random sampling technique, samples were collected from X-IPA-1 and X-IPA-2 classes in State Senior High School 6 Semarang. Both classes acquired similar treatment; cooperative learning with scaffolding strategy. Participants in this study consisted of a mathematics instructor teaching in X-IPA-1 and X-IPA-2 based on the timetable and an observer. The authors conducted data collection from January to March 2019.

Methods used in the data collection are written test, questionnaire, and interview. The written test is a formative test given twice, in the second and fourth meeting. It contained trigonometry within 5 question items. The questionnaire is about the level of mathematics anxiety given to students before and after learning with scaffolding. It contained 30 question items developed based on indicators of mathematics anxiety [8]. It was arranged based on a Likert scale from 1 to 4.

The authors selected some students as interview subjects through purposive technique. An in-depth interview was conducted to collect information about student mathematics anxiety level before and after learning within a scaffolding strategy. To measure the level of mathematics anxiety, the authors used criteria as described in Table 1.

Table 1. Measure of Mathematics Anxiety Level

\begin{tabular}{ccc}
\hline $\begin{array}{c}\text { Mathematics Anxiety Score } \\
(\text { Range } 0-100)\end{array}$ & $\begin{array}{c}\text { Mathematics Anxiety Score } \\
(\text { Range } 0,0-5,00)\end{array}$ & $\begin{array}{c}\text { Category of } \\
\text { Mathematics Anxiety }\end{array}$ \\
\hline $0<$ MA $\leq 25$ & $0<$ MA $\leq 1,25$ & Low \\
\hline $25<$ MA $\leq 50$ & $1,25<$ MA $\leq 2,50$ & Average (Moderate) \\
\hline $50<$ MA $\leq 75$ & $2,50<$ MA $\leq 3,75$ & High \\
\hline $75<$ MA $\leq 100$ & $3,75<$ MA $\leq 5,00$ & Very High \\
\hline
\end{tabular}

Analysis of quantitative data in this study used a statistic test technique: sample normality test, paired sample t-test, and N-gain test. Analysis of qualitative data used interactive method i.e., data collection, data reduction, data display, and drawing conclusion. Data validation techniques used to source and method triangulation [18].

The following is an example of a trigonometry question in the formative test in class: Rossy is going to measure the wide of the river without crossing. He measures as follows: $\mathrm{He}$ stands in point $\mathrm{A}$ and measures the angle to point $\mathrm{C}$ across the river as $50^{\circ}$. Then, he steps right as far as 300 meters and stands on point B. From point B, he measures the angle to point $\mathrm{C}$ as $30^{\circ}$. Help Rossyto measure the wide of the river!

\section{RESULT AND DISCUSSION}

The original data of samples was obtained from scores of the first formative test in X-IPA1 and X-IPA-2. Before conducting the learning with scaffolding, the data normality had been tested with the significance level as $\alpha=0.075>0.05$ which meant that the sample was from a normaly distributed population. The first scores were compared to the second formative test scores through the implementation of a scaffolding strategy. Statistic description of test scores before and after learning with scaffolding is as displayed in Table 2. 
Numerical: Jurnal Matematika dan Pendidikan Matematika, 4(1), Juni 2020, 13-22

Imam Kusmaryono, Akbar Muntoha Gufron, Achmad Rusdiantoro

Table 2. Statistic description of average scores before and after scaffolding strategy

\begin{tabular}{cccccccc}
\hline \multirow{2}{*}{ Class } & \multirow{2}{*}{$N$} & \multicolumn{3}{c}{$\begin{array}{c}\text { Score After Learning with } \\
\text { Scaffolding }\end{array}$} & \multicolumn{3}{c}{$\begin{array}{c}\text { Score Before Learning with } \\
\text { Scaffolding }\end{array}$} \\
\cline { 3 - 8 } & & Range & $\mu_{2}$ & $\sigma_{\bar{x}}$ & Range & $\mu_{1}$ & $\sigma_{\bar{x}}$ \\
\hline X-IPA-1 & 30 & $80-95$ & 85.4 & 8.3132 & $65-90$ & 78.0 & 5.6324 \\
\hline X-IPA-2 & 30 & $76-100$ & 86.6 & 7.6878 & $70-95$ & 80.0 & 8.0301 \\
\hline Total & 60 & & & & & & \\
\hline
\end{tabular}

Based on Table 2, the authors conducted an analysis of Paired Samples t-Test and obtained that value of significant (Sig.2-tailed) $=0,000<0,05$ so $\mathrm{H}_{\mathrm{o}}$ was rejected, which meant that there was a difference between scores of student learning outcome before $\left(\mu_{1}\right)$ and after $\left(\mu_{2}\right)$ following the learning with scaffolding in X-IPA-1and X-IPA-2. Thus, to determine the percentage of increase in the average score of learning achievement, the authors conducted Normality-gain $(N$ gain) test [19]. Interpretation of normalized $N$-gain index from Table 2 indicated that there was increase in a average score of students' learning achievement in X-IPA-1 after having learned with scaffolding strategy as $33.6 \%$, and in X-IPA-2 as 33.0\%. The increase of scores was quite significant, so the learning with scaffolding was arguably quite effective to improve student achievement in learning [15],[19].

The following is an example of a student (S.3) answer while solving trigonometry question before and after the implementation of scaffolding in learning (see Figure 2).

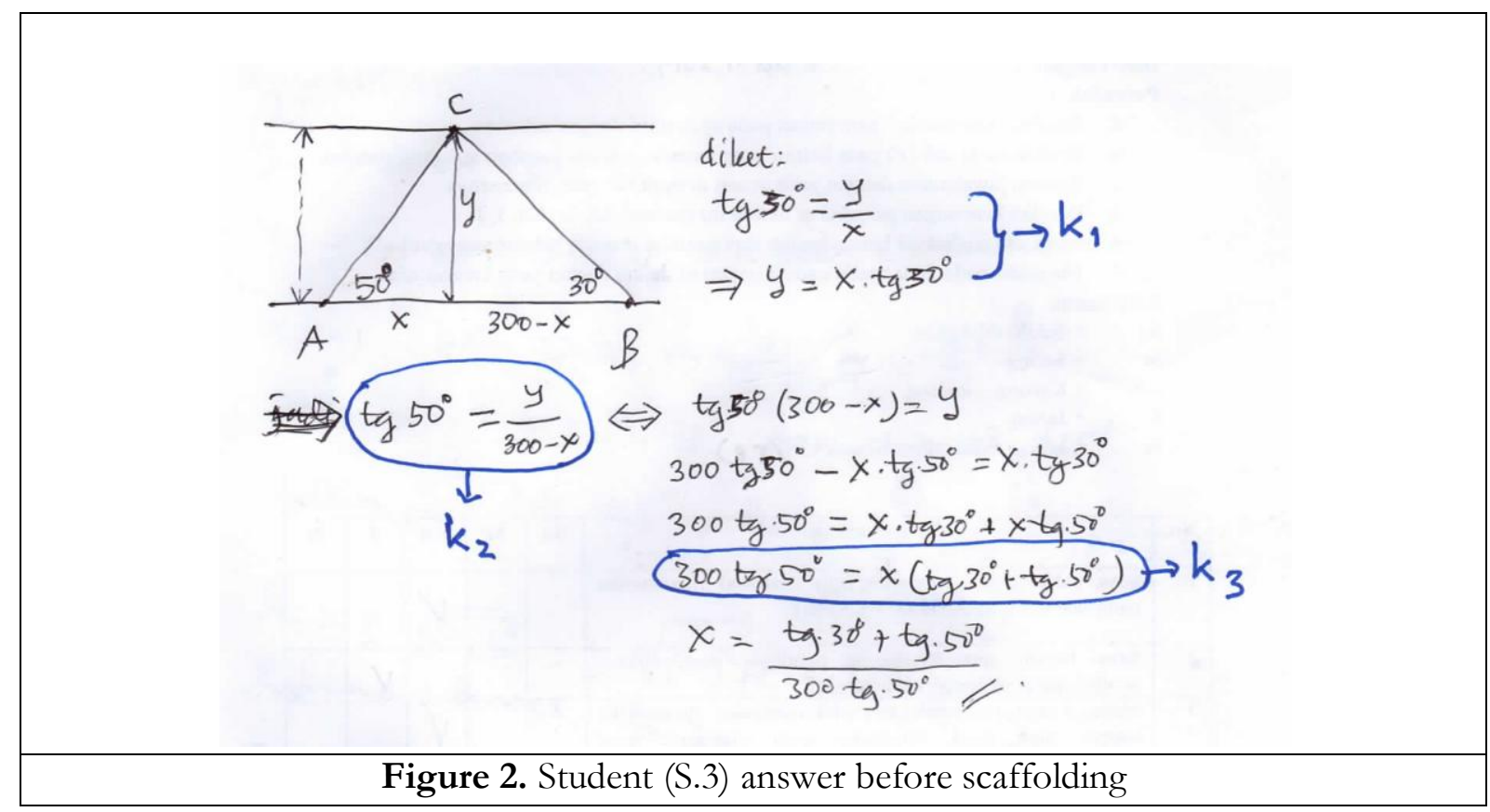

Based on the analysis on student (S.3) aaswer in Figure 2, the authors had identified 3 errors by the student while solving the problem and decoded them with code $\left(k_{1}\right),\left(k_{2}\right)$, and $\left(k_{3}\right)$. The teacher actually believed that the student had the potential to fix the thinking process as Vygotsky theory about Zone of Proximal Development (ZPD). Moreover, the teacher gave a 
chance to student to reflect on what he had done and scaffolding as needed. The following is an excerpt of an interview between the teacher and student (S.3) while having a reflection.

Teacher : Did you realize that your answer was incorrect?

Student (S.3) : I did, Sir, but I had no idea which one was the error.

Teacher : Look at the codes $\mathrm{k}_{1}, \mathrm{k}_{2}$, and $\mathrm{k}_{3}$ on your work.

Student(S.3) : Why are these $\mathrm{k}_{1}, \mathrm{k}_{2}$, and $\mathrm{k}_{3}$ incorrect?

Teacher : Based on figure you made, $\operatorname{tgn} 50^{\circ}=\mathrm{y} / \mathrm{x}$, So you could obtain the value $\mathrm{y}=\mathrm{x} \cdot \operatorname{tgn} 50^{00}$

Student(S.3) : Oh I see, Sir. After that, I could find the $\mathrm{x}$

Teacher : Very good. Please finish it through the equation of $\operatorname{tgn} 30^{\circ}$

Student(S.3) : Ok, Sir, I'm working on the equation tgn $30^{\circ}=y /(300-x)$

Teacher : How is the mathematical equation to find the $\mathrm{x}$ ?

Student(S.3) : $\operatorname{tgn} 30^{\circ}(300-\mathrm{x})=\mathrm{x} \cdot \operatorname{tgn} 50^{\circ}$

Teacher : Very good, that is a correct step to find the $\mathrm{x}$.

Student(S.3) : After the $\mathrm{x}$ is found, I am going to input it into the equation $\mathrm{y}=$ $\mathrm{x} . \operatorname{tgn} 50^{\circ}$ to obtain the wide of the river.

Considering the interview between teacher and student (S.3) indicated that the teacher had implemented scaffolding to help students fix the error. The scaffolding was given by the teacher through limited directions or keywords. After reflection process and scaffolding from the teacher, the student could easily understand the problem and got errors no more [15],[20],[21],[11]. The following is an example of student answer after receiving scaffolding from the teacher (Figure 3).

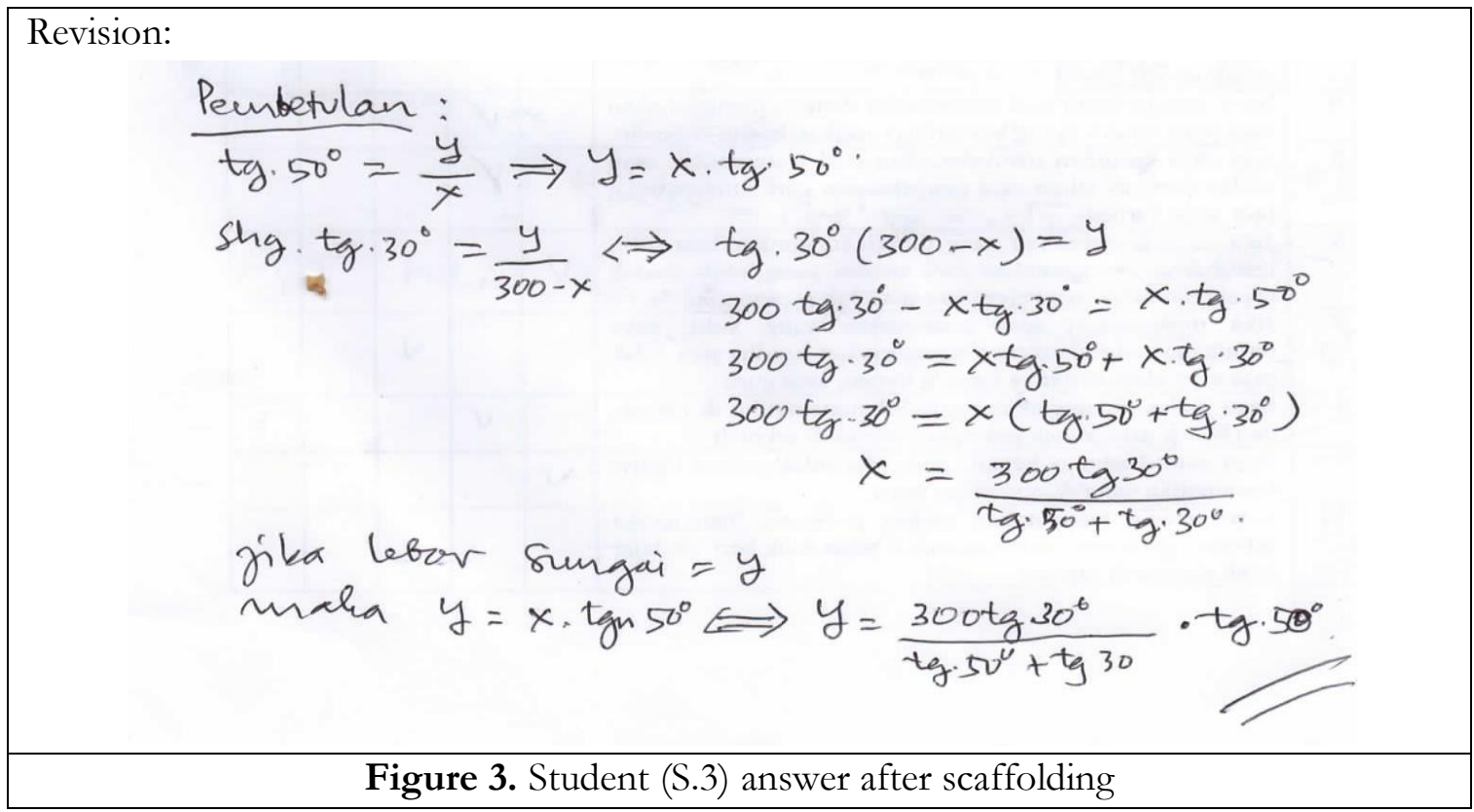

Statistic description of student mathematics anxiety questionnaire before and after following the learning with scaffolding strategy is presented in Table 3 below. 
Numerical: Jurnal Matematika dan Pendidikan Matematika, 4(1), Juni 2020, 13-22

Imam Kusmaryono, Akbar Muntoha Gufron, Achmad Rusdiantoro

Table 3. Statistic description of mathematics anxiety questionnaire

\begin{tabular}{llccc}
\hline No. & $\begin{array}{c}\text { Factor of } \\
\text { Mathematics } \\
\text { Anxiety }\end{array}$ & $\begin{array}{c}\text { Average Score } \\
\text { Before Scaffolding }\end{array}$ & $\begin{array}{c}\text { Average Score } \\
\text { AfterScaffolding }\end{array}$ & $\begin{array}{c}\text { Average Change } \\
\text { (Decrease) }\end{array}$ \\
\hline 1. & Subject Personality & 3,98 & 1,10 & $-2,88$ \\
\hline 2. & Parents & 2,54 & 2,25 & $-0,29$ \\
\hline 3. & $\begin{array}{l}\text { Mathematics } \\
\text { Content }\end{array}$ & 3,70 & 2,09 & $-1,61$ \\
\hline 4. & $\begin{array}{l}\text { Mathematics } \\
\text { Teacher }\end{array}$ & 3,66 & 1,94 & $-1,72$ \\
\hline & Average $(1,2,3,4)$ & 3,47 & 1,84 & $-1,62$ \\
\hline$*$ & Average $(1,3,4)$ & 3,78 & 1,71 & $-2,07$ \\
\hline
\end{tabular}

Considering that this questionnaire just identified the mathematics anxiety at school, the aspect number 2 (parents' anxiety factor) was neglected. Table 3 indicated that average score of student mathematics anxiety before the learning with scaffolding was on high category (3.78). After the teacher implemented scaffolding in the learning, the anxiety decreased on moderate category (1.71) with average decrease as 2.07 point.

Result of interpretation on normalized $N$-gain index fromTable 3 indicated that there was a dcrease of student anxiety score after having a learning with scaffolding as $90.4 \%$. The decrease percentage was greatly significant, so the learning with scaffolding was arguably quite effective to reduce the student mathematics anxiety.

Reconsidering Table 3, it could be said that, before the implementation of scaffolding in learning, the most significant factors of mathematics anxiety were (1) Subject perception on mathematics, (2) content (material), and (3) mathematics teacher. However, after the scaffolding implementation, all factors of mathematics anxiety decreased significantly. The scaffolding gave to students to reflect their work and led them to initial knowledge to solve problems they had [10] and also improved positive disposition toward mathematics [16],[23].

In order to collect further information about mathematics anxiety and disposition toward the implementation of scaffolding in learning, the authors asked some questions in an interview. The following is the result of an interview with the selected subject. Student (S.1) represented lower group, student (S.2) and (S.3) represented the middle group, while the student (S.4) represented the upper group.

\begin{tabular}{lrl}
\hline Question 1 & : & $\begin{array}{l}\text { Why did you look so nervous when the teacher asked you to } \\
\text { solve mathematics question in front of the class? }\end{array}$ \\
\hline Student 1(S.1) & $: \begin{array}{l}\text { I was afraid that the teacher would get mad of me getting wrong on } \\
\text { the answer. It would be a shame for me. }\end{array}$ \\
Student2 (S.2) & $\begin{array}{l}\text { Working on the question in front of the class made me nervous and } \\
\text { less concentrated, because of teacher supervision. }\end{array}$ \\
Student3 (S.3) & $: \begin{array}{l}\text { I could not concentrate, my hand shook, and I was sweaty if the } \\
\text { teacher told me to go in front of the class. }\end{array}$ \\
Student4 (S.4) & $:$ I was quite challenged about self-esteem and achievement. \\
\hline
\end{tabular}


Students' response toward question 1 in the previous excerpt indicated that their anxiety toward mathematics was caused by the teacher. They were afraid of the teacher would get mad at their error. They implicitly mentioned the teacher as the source of their in comfort [3][9]. Nevertheless, there was a student (S.4) felt quite challenged to present the solution in front of the class.

\begin{tabular}{lll}
\hline Question 2 & : $\begin{array}{l}\text { Why were you anxious while thinking about mathematics in } \\
\text { the National Exam (Ujian Nasional)? }\end{array}$ \\
\hline Student 1 (S.1) & $: \begin{array}{l}\text { I must study hard to succeed in the exam since it determines } \\
\text { graduation. }\end{array}$ \\
Student2 (S.2) & $\begin{array}{l}\text { I do not feel ready enough to have mathematics in National Exam } \\
\text { with a difficult question. }\end{array}$ \\
Student3 (S.3) & $: \begin{array}{l}\text { I am worried of too many content or materials that should be } \\
\text { mastered, and of bad scores. }\end{array}$ \\
Student4 (S.4) & $:$ I should prepare myself by studying more to succeed.
\end{tabular}

Result of student response toward question 2 indicated that students still considered mathematics was the cause of their anxiety while having national exam or test. A perception saying that mathematics is a difficult subject still becomes an obstacle for students to succeed in studying mathematics. Furthermore, they should construct the perception to consider mathematics is just similar to any other subject and hard work will bring success to increase learning achievement [6].

\begin{tabular}{lll}
\hline Question 3 & $\begin{array}{l}\text { Apakah pemberian scaffolding dalam pembelajaran cukup } \\
\text { membantu menangani kesulitan belajar Anda ? }\end{array}$ \\
\hline Student1 (S.1) & $: \begin{array}{l}\text { It was greatly helpful for me to receive such assistance. The teacher } \\
\text { accompanied me to revise my work, so the errors were fixed. }\end{array}$ \\
Student2 (S.2) & $\begin{array}{l}\text { The teacher took care of me so much. I was so helped by the } \\
\text { teacher's guidance, so I did no errors. }\end{array}$ \\
Student3 (S.3) & $\begin{array}{l}\text { I was much helped to be a mathematician. I could find the solution } \\
\text { with a few assistance from the teacher. } \\
\text { Student4 (S.4) }\end{array}$ \\
& $\begin{array}{l}\text { It was quite helpful for me to confirm my answer to the teacher. I felt } \\
\text { he opened my mind. }\end{array}$
\end{tabular}

Result of student response toward question 3 indicated that the teacher had provided a well-conducted scaffolding, by guiding the students of giving key instructions, signs, questions and correction, so they could easily step or develop to higher thinking process [11],[21]. After scaffolding implementation, the students could conduct reflection and revise the previous errors [11]. It meant that scaffolding has become a useful strategy to help students develop through different Zone of Proximal Development (ZPD) [15],[20],[21]. 


\begin{tabular}{lll}
\hline Question 4 & : & $\begin{array}{l}\text { Apakah penerapan scaffolding dalam pembelajaran telah } \\
\text { mengubah persepsi Anda terhadap peran guru yang efektif ? }\end{array}$ \\
\hline Student 1 (S.1) & $: \begin{array}{l}\text { I felt the teacher was the helper in my difficulties, and became } \\
\text { friendly to students. }\end{array}$ \\
Student2 (S.2) & $: \begin{array}{l}\text { The teacher was like my friend, no shy to ask anymore. } \\
\text { Student3 (S.3) }\end{array}$ & $\begin{array}{l}\text { Incredibly effective, and I always hope the teacher is ready and } \\
\text { willing to help. }\end{array}$ \\
Student4 (S.4) & $\begin{array}{l}\text { The role of the teacher as facilitator was very effective to help us } \\
\text { when needed. }\end{array}$ \\
\hline
\end{tabular}

Student response toward question 4 suggested that the teacher had an opportunity to break negative stereotypes and myths about mathematics teachers who seemed to be unconcerned or insensitive toward the student obstacle. Scaffolding also helped to create a positive circumstance in the classroom so it could become a motivation for students to study mathematics without fear [24]. The teacher also had an opportunity to motivate students to believe that things such as gender stereotype and mathematics nature must not restrict their choices to learn mathematics. It could be done by being friendly and open [24].

Based on the result and discussion of the study, it could be summed up that implementation of scaffolding steps could run correctly and effectively for students. While implementing the scaffolding, the teacher concerned and appreciated ideas from students then led them to the kinds of decisions and choices that they should make to develop and repair ideas [15],[21]. The scaffolding was successful because the teacher and students could put themselves in the correct position. Role of the teacher was as the source, facilitator, and the one to monitor student activities in the learning to run well.

While implementing scaffolding to students, the observer found that the teacher also provided contingency assistance, based on the need and/or obstacle the students had. There was a switch of student thinking process in the reflection stage after having scaffolding assistance. It meant that the scaffolding could become a useful strategy to help students step through different Zone of Proximal Development (ZPD) [15],[20],[21]. Scaffolding involves active support from the teacher for students while they are working on tasks that could not be done alone. Scaffolding could be reduced or even stopped if the students start to be able to construct their own knowledge [15],[20],[21].

\section{CONCLUSION AND SUGGESTION}

Conclusion of this study is that mathematics learning within scaffolding is was effective to improve student learning achievement and decrease the level of students' mathematics anxiety. By scaffolding, the students succeeded to conduct a reflection and revise the errors while solving problems. It meant that the scaffolding could become a useful strategy to help students step through different Zone of Proximal Development (ZPD). Scaffolding strategy had created a positive circumstance in the classroom so it could motivate students to study mathematics without fear and anxiety.

Furthermore, the authors suggest that teacher could reduce students' mathematics anxiety and learning obstacles through active learning within scaffolding strategy. The scaffolding 
assistance should be considered in terms of its function to serve and how to accommodate student understanding.

\section{REFERENCES}

[1] S. Subandi, C. Choirudin, M. Mahmudi, N. Nizaruddin, and H. Hermanita, "Building Interactive Communication with Google Classroom," International Journal of Engineering \& Technology, vol. 7, no. 2.13, pp. 460-463, Apr. 2018, doi: https://doi.org/10.14419/ijet.v7i2.13.18141.

[2] K. Gravemeijer, M. Stephan, C. Julie, F. L. Lin, and M. Ohtani, "What Mathematics Education May Prepare Students for the Society of the Future?," International Journal of Science and Mathematics Education, vol. 15, pp. 105-123, 2017, doi: https://doi.org/10.1007/s10763017-9814-6.

[3] E. Zakaria and M. Syamaun, "The Effect of Realistic Mathematics Education Approach on Students' Achievement And Attitudes Towards Mathematics," Mathematics Education Trends and Research, vol. 2017, no. 1, pp. 32-40, 2017, doi: https://doi.org/10.5899/2017/metr00093.

[4] M. S. Anwar, C. Choirudin, E. F. Ningsih, T. Dewi, and A. Maseleno, "Developing an Interactive Mathematics Multimedia Learning Based on Ispring Presenter in Increasing Students' Interest in Learning Mathematics," Al-Jabar: Jurnal Pendidikan Matematika, vol. 10, no. 1, pp. 135-150, Jul. 2019, doi: https://doi.org/10.24042/ajpm.v10i1.4445.

[5] P. Grootenboer and M. Marshman, "The Affective Domain, Mathematics, and Mathematics Education," in Mathematics, Affect and Learning, Springer Science+Business Media Singapore, 2016, pp. 13-24.

[6] Z. Wang, S. L. Lukowski, S. A. Hart, and I. M. Lyons, "Is Mathematical Anxiety Always Bad for Math Learning: The Role of Math Motivation," Psychological Science, vol. 26, no. 12, pp. 1863-1876, 2016, doi: https://doi.org/10.1177/0956797615602471.Is.

[7] Y. F. Zakariya, "Development of Mathematics Anxiety Scale: Factor Analysis as a Determinant of Subcategories," Journal of Pedagogical Research, vol. 2, no. 2, pp. 135-144, 2018.

[8] C. M. Ganley and A. L. Mcgraw, "The Development and Validation of a Revised Version of the Math Anxiety Scale for Young Children," Frontiers in Psychology, vol. 7, no. 1181, pp. 1-18, 2016, doi: https://doi.org/10.3389/fpsyg.2016.01181.

[9] A. Dowker, A. Sarkar, and C. Y. Looi, "Mathematics anxiety: What have we learned in 60 years?," Frontiers in Psychology, vol. 7, no. APR, 2016, doi: https://doi.org/10.3389/fpsyg.2016.00508.

[10] I. P. Maharani and S. Subanji, "Scaffolding Based on Cognitive Conflict in Correcting the Students' Algebra Errors," International Electronic Journal of Mathematics Education, vol. 13, no. 2, pp. 67-74, 2018, doi: https://doi.org/10.12973/iejme/2697.

[11] K. A. Wibawa, T. Nusantara, Subanji, and I. N. Parta, "Defragmentation of Student' s Thinking Structures in Solving Mathematical Problems based on CRA Framework," Journal of Physics: Conf. Series, vol. 1028, no. 12150, pp. 1-8, 2018.

[12] I. Kusmaryono and N. Ulia, "Interaksi Gaya Mengajar dan Konten Matematika sebagai Faktor Penentu Kecemasan Matematika," Mosharafa: Jurnal Pendidikan Matematika Mosharafa: 
Jurnal Pendidikan Matematika, vol. 9, no. 1, pp. 143-154, 2020, doi: https://doi.org/10.31980/mosharafa.v9i1.634.

[13] Choirudin, Eka Fitria Ningsih, M. Saidun Anwar, Intan Ratna Sari, and Suci Amalia, "Pengembangan Perangkat Pembelajaran Etnomatematika Pada Situs Purbakala Pugung Raharjo," Pi: Mathematics Education Journal, vol. 3, no. 1, pp. 18-27, 2020, doi: https://doi.org/10.21067/pmej.v3i1.3755.

[14] Apri Wahyudi and Choirudin, "Pengembangan Alat Peraga Pembelajaran Matematika Materi Perkalian Berbasis Montessori," Jurnal Manajemen Pendidikan Islam Al-Idarah, vol. 4, no. 2, pp. 33-39, 2019.

[15] S. Puntambekar and R. Hubscher, "Environment: What Have We Gained and What Have We Missed?," Educational Phychologist, vol. 40, no. 1, pp. 1-12, 2015, doi: https://doi.org/10.1207/s15326985ep4001.

[16]J. van de Pol, M. Volman, F. Oort, and J. Beishuizen, "The effects of scaffolding in the classroom : support contingency and student independent working time," Instructional Science, vol. 43, no. 5, pp. 615-641, 2015, doi: https://doi.org/10.1007/s11251-015-9351-z.

[17]B. Eun, "The zone of proximal development as an overarching concept: A framework for synthesizing Vygotsky's theories," Educational Philosophy and Theory, vol. 51, no. 1, pp. 18-30, 2019, doi: https://doi.org/10.1080/00131857.2017.1421941.

[18] M. B. Miles and M. A. Huberman, Analisis Data Kualitatif: Buku Sumber Tentang Metode-Metode Baru, 11th ed., no. 1. Jakarta: Universitas Indonesia (UI-Press), 2012.

[19] H. Hendriana, U. rahmat Slamet, and U. Sumarmo, "Mathematical connection ability and self-confidence (an experiment on Hunior High School students through Contextual Teaching and learning with Mathematical Manipulative)," International Journal of Education, vol. 8, no. 1, pp. 1-11, 2018, doi: https://doi.org/10.17509/IJE.V8I1.1726.

[20] S. Sofiatun, P. Deniyanti, and L. El, "The effect of scaffolding techniques on the ability of student' s reasoning ability and mathematics anxiety reviewed from gender," Unnes Journal of Mathematics Education, vol. 7, no. 1, pp. 63-71, 2018, doi: https://doi.org/10.15294/ujme.v7i1.22574.

[21]J. Van De Pol, M. Volman, and J. Beishuizen, "Scaffolding in Teacher - Student Interaction : A Decade of Research," Educational Psychology Review, vol. 22, no. 3, pp. 271-296, 2015, doi: https://doi.org/10.1007/s10648-010-9127-6.

[22]B. R. Belland and E. Evidence, Instructional Scaffolding in STEM Education. Switzerland: Springer International Publishing AG Switzerland, 2016.

[23] I. Kusmaryono, H. Suyitno, D. Dwijanto, and N. Dwidayati, "The Effect of Mathematical Disposition on Mathematical Power Formation: Review of Dispositional Mental Functions," International Journal of Instruction, vol. 12, no. 1, pp. 343-356, 2019, doi: https://doi.org/10.29333/iji.2019.12123a.

[24] H. I. Van Mier, T. M. J. Schleepen, and F. C. G. Van den Berg, "Gender differences regarding the impact of math anxiety on arithmetic performance in second and fourth graders," Frontiers in Psychology, vol. 9, no. JAN, pp. 1-13, 2019, doi: https://doi.org/10.3389/fpsyg.2018.02690. 